\title{
LONG-TERM EFFECTS OF TEBUTHIURON ON BROMUS TECTORUM
}

\author{
Dana M. Blumenthal ${ }^{1}$, Urszula Norton ${ }^{2}$, Justin D. Derner ${ }^{2}$, and Jean D. Reeder ${ }^{2}$
}

\begin{abstract}
Aвstract.-Use of herbicides to thin dense stands of Artemisia spp. (sagebrush) can free up resources for herbaceous plants and increase forage production, but may also facilitate weed invasion. We revisited a sagebrush thinning experiment in a north central Wyoming big sagebrush-grassland 11 years after application of tebuthiuron $(\mathrm{N}-[5-(1,1-$ dimethylethyl)-1,3,4-thiadiazol-2-yl]-N-N'-dimethylurea) to determine the long-term responses of shrubs, available soil resources, perennial grasses, and Bromus tectorum L. (downy brome). Tebuthiuron reduced shrub cover by more than half, from $31 \%$ in untreated plots to $15 \%$ in treated plots $(P=0.002)$, and increased downy brome cover approximately 4 -fold, from $0.9 \%$ in untreated plots to $3.5 \%$ in treated plots $(P=0.02)$. Treatment with tebuthiuron also resulted in marginally significant increases in cover of perennial grasses (from $9 \%$ to $12.3 \% ; P=0.07$ ) and bare ground (from $39.1 \%$ to $43.9 \% ; P=0.08)$. In comparisons of resource availability among microsites, available $\mathrm{NO}_{3}$ was higher under dead sagebrush than under live sagebrush $(P=0.03)$. No significant differences in soil water content were detected. The relatively recent expansion of downy brome populations at this site and the high $\mathrm{NO}_{3}-\mathrm{N}$ levels observed under dead sagebrush suggest that conditions facilitating downy brome invasion may persist for many years following sagebrush thinning. We demonstrate that sagebrush thinning can cause increases in downy brome populations years after initial treatment and suggest that managers should use caution when considering thinning sagebrush if downy brome is present, even if initial populations are small.
\end{abstract}

Keywords: bare ground, cheatgrass, downy brome, invasion, land management, nitrogen, $\mathrm{NO}_{3}$, resources, sagebrush thinning, water, weed.

Thinning dense stands of sagebrush with herbicides can increase forage production while causing less disturbance than mechanical techniques and fire (Hull et al. 1952, Hyder and Sneva 1956, Hedrick et al. 1966, Miller et al. 1980). Thinning influences forage production by making resources previously used by sagebrush available to herbaceous plants. Depending on site characteristics and postthinning management, increases in forage production may be sustained for several to 35 years (Harniss and Murray 1973, Bartolome and Heady 1978, Sturges 1993, Olson and Whitson 2002, McDaniel et al. 2005). Unfortunately, increases in resource availability with sagebrush thinning may also encourage weed establishment. If established herbaceous perennials are sufficiently common, they can take up newly available nutrients (Burke et al. 1987) and water, particularly water within the upper soil profile (Hyder and Sneva 1956, Sturges 1993). If resources are not quickly preempted by desired species, however, invasive species may benefit. Many invasive plant species grow rapidly, have short generation times, and allo- cate a high percentage of resources to reproduction and dispersal. These life history characteristics provide a competitive advantage in environments with abundant available resources (Baker 1965, Chapin 1980). Bromus tectorum (downy brome) is a prime example, reaching reproductive maturity in as little as 6-8 weeks, and producing tens of thousands of seeds per $\mathrm{m}^{2}$ (Hulbert 1955, Mack and Pyke 1983). It is also the most abundant invader of sagebrush ecosystems, infesting more than 40 million ha in the United States (DiTomaso 2000).

Concerns about the response of downy brome to sagebrush removal are not new. Piemeisel (1951) detailed a successional trajectory following mechanical removal of sagebrush that passes from Salsola kali var. tenuifolia Tausch (Russian thistle) through Decurainia sophia (L.) Webb (flixweed) and Sisymbrium altissimum L. (tumble mustard) to downy brome, and eventually to native perennial species. Chemical control of sagebrush avoids soil disturbance but also stimulates weed invasion. For example, Hedrick et al. (1966) found that downy brome dominated chemically treated

\footnotetext{
${ }^{1}$ Crops Research Laboratory, 1701 Centre Avenue, Fort Collins, CO 80526. E-mail: dana.blumenthal@ars.usda.gov

${ }^{2}$ United States Department of Agriculture, Agricultural Research Service, Rangeland Resources Research Unit, Cheyenne, WY 82009.
} 
rangeland in poor condition for up to 7 years. More recently, tebuthiuron (N-[5-(1,1-dimethylethyl)-1,3,4-thiadiazol-2-yl]-N-N' dimethylurea) has been recommended for its ability to control sagebrush while leaving forbs in place, thereby minimizing adverse effects on plant and animal diversity (Johnson et al. 1996, Olson and Whitson 2002). Shrub control and herbaceous biomass production increase in proportion to the tebuthiuron application rate (Whitson and Alley 1984, Whitson et al. 1988, McDaniel et al. 2005). At several sites, however, trends were observed towards higher biomass of downy brome in treated plots (Olson and Whitson 2002), and at 1 site downy brome dominated treated plots 7 years after tebuthiuron application (Whitson et al. 1988).

Although the potential for short-term increases in downy brome abundance following sagebrush control has been well documented, there are few long-term studies of the effect of sagebrush thinning on brome invasion. Given the emergence of downy brome as one of the most problematic rangeland weeds in North America (Young and Allen 1997), an important priority is to determine whether increases following sagebrush thinning represent temporary successional trends or longer-term changes in plant community composition. In this study we revisited an experimental site that was treated with tebuthiuron in 1993 and did not show an increase in downy brome abundance with tebuthiuron application 2 or 4 years after treatment (Olson and Whitson 2002). Our objective was to determine the long-term effects of tebuthiuron on downy brome invasion and on soil resources that may influence downy brome invasion.

\section{METHODS \\ Study Site and \\ Experimental Design}

The study site was located in a sagebrushgrassland ecosystem dominated by Artemisia tridentata Nutt. ssp. wyomingensis Beetle \& Young (Wyoming big sagebrush), on the Tim McKinney ranch $\left(42^{\circ} 42^{\prime} 28^{\prime \prime} \mathrm{N}, 108^{\circ} 36^{\prime} 21^{\prime \prime} \mathrm{W}\right)$, approximately $22 \mathrm{~km}$ southeast of Lander, Wyoming (Olson and Whitson 2002). The elevation was $1696 \mathrm{~m}$. Over the 10 years between tebuthiuron application and this study, annual precipitation in Lander averaged $95 \%$ of the 340-mm mean. Annual precipitation was considerably lower than average during the 3 years immediately preceding this study: $218 \mathrm{~mm}$ in 2000, $137 \mathrm{~mm}$ in 2001, and $205 \mathrm{~mm}$ in 2002. Annual precipitation and June-September precipitation were $261 \mathrm{~mm}$ and $100 \mathrm{~mm}$ in 2003, and $368 \mathrm{~mm}$ and $174 \mathrm{~mm}$ in 2004 (Western Regional Climate Center). The site was grazed annually at a moderate stocking rate throughout the study. Spring and fall grazing occurred in alternate years, and the site was grazed prior to vegetation sampling in 2004 .

In the original study a randomized complete block design was used, with 3 replications of 4 herbicide treatments: 0 (Control), $0.1,0.2$, or $0.4 \mathrm{~kg}$ ai $\cdot \mathrm{ha}^{-1}$ tebuthiuron (Olson and Whitson 2002). Individual plots were 402 $\mathrm{m} \times 102 \mathrm{~m}$ and separated by $25-\mathrm{m}$ buffers. The principle native species, besides Wyoming big sagebrush, were Chrysothamnus viscidiflorus Nutt. (rabbitbrush), Pascopyrum smithii [(Rydb.) A. Löve] (western wheatgrass), Koeleria macrantha (Ledeb.) J.A. Schultes (June grass), Phlox hoodii Richards. (phlox), and Astragalus bisulcatus (Hook.) Gray (two-grooved milkvetch; Olson and Whitson 2002). Downy brome was the most prevalent invasive weed. Although differences were not statistically significant, in 1995 and 1997 more downy brome was found in untreated than treated plots (Olson and Whitson 2002). Thus, tebuthiuron did not increase downy brome during the first 4 years of this study.

In summer 2004, eleven years after herbicide treatment, we measured canopy cover of downy brome, perennial grasses, and shrubs, and cover of bare ground in control plots and plots treated with the highest level of tebuthiuron $\left(0.4 \mathrm{~kg}\right.$ ai $\left.\cdot \mathrm{ha}^{-1}\right)$. We also measured the effect of sagebrush death on soil resources in 2003, comparing soil water, total organic C and $\mathrm{N}$, and mineral $\mathrm{N}\left(\mathrm{NO}_{3}-\mathrm{N}\right.$ and $\left.\mathrm{NH}_{4}-\mathrm{N}\right)$ among 3 surface microsites: live sagebrush, dead sagebrush, and sagebrush interspaces.

\section{Vegetation Sampling}

Because the experiment had limited replication and patchy distribution of vegetation types within plots, we attempted to maximize the area sampled within each plot. This required sampling methods that were different from those used in 1994 and 1997. We estimated canopy cover of shrubs, perennial grasses, and downy brome, and cover of bare 
ground using Daubenmire cover classes (Daubenmire 1959) in a total of 2088 subplots $(1 \mathrm{~m}$ $\times 0.5 \mathrm{~m}$ ) in August 2004. Subplots were placed at $5 \mathrm{~m}$ intervals along nine $200-\mathrm{m}$ transects (41 subplots $\cdot$ transect $\left.^{-1}\right)$ in each plot, for a maximum of 369 subplots per plot. Transects were located in the center of plots and separated by $10 \mathrm{~m}$. Subplots within $10 \mathrm{~m}$ of atypical landscape features, including roads, ditches, streams, and wetland areas, were not measured. Therefore, to ensure a minimum of 300 subplots in each whole plot, additional transects were randomly assigned to locations between the original transects where necessary. Cover classes were converted to the median of each cover range for data analysis.

\section{Soil Resource Sampling}

Given the small number of replications and the high variability among soil samples in preliminary tests, we did not attempt to measure differences in soil resources among herbicide treatments. Instead, we examined the effect of tebuthiuron on soil resources indirectly by measuring the effects of Wyoming big sagebrush death on soil resources. Effects of sagebrush death on soil resources were determined by comparing resource measurements taken from under dead sagebrush, under live sagebrush, and in sagebrush interspaces. Because dead sagebrush plants were rare in untreated plots, these comparisons were conducted only in areas treated with the highest level of tebuthiuron $\left(0.4 \mathrm{~kg}\right.$ ai $\left.\cdot \mathrm{ha}^{-1}\right)$. Soil samples were collected from randomly selected locations within 6 (for mineral $\mathrm{N}$ and soil water) or 9 (for total C and N) blocks, each comprised of a randomly selected dead sagebrush plant paired with the nearest live sagebrush plant and sagebrush interspace.

For mineral $\mathrm{N}$ and water, soil samples were collected at 19 dates between May 2003 and November 2003 (approximately 10-day intervals). Three 1.9 -cm-diameter $\times 10$-cm cores were pooled from each microsite type-live sagebrush canopy, dead sagebrush canopy, and sagebrush interspace-using a soil step-probe. Soil samples from underneath live and dead sagebrush canopies were obtained approximately $15 \mathrm{~cm}$ away from the shrub main stem. Soil cores were bagged, stored on ice, and transported to the laboratory for immediate extraction in $1 \mathrm{M} \mathrm{KCl}$. Extractable mineral N was determined on a $1 \mathrm{M} \mathrm{KCl}$ extract using a continuous flow colorimetric procedure (Lachat Instruments, Hach Company, Loveland, CO); $\mathrm{NH}_{4}-\mathrm{N}$ was determined with a sodium salicylate-based method, and $\mathrm{NO}_{3}-\mathrm{N}$ with a cadmium reduction method. To measure effects of microsite on gravimetric water content deeper in the soil profile, one 2.2 -cm-diameter $\times 50$ cm-deep soil core was taken from each microsite-block combination in June, July, August, and September 2003. Soil moisture was determined gravimetrically by drying samples to a constant weight at $105^{\circ} \mathrm{C}$. To obtain total $\mathrm{C}$ and $\mathrm{N}$, one 5 -cm-diameter $\times 15$-cm core was collected from each microsite-block combination in May 2003. Following removal of all visible roots, soil was passed through a $2-\mathrm{mm}$ sieve, air-dried, and ground with a powder roller. Total $\mathrm{C}$ and $\mathrm{N}$ were determined with a Carlo Erba NA 1500 automatic carbon-nitrogen analyzer (Haake Buckler Instruments Inc., Saddle Brook, NJ). Inorganic C was measured with a modified pressure-calcimeter method (Sherrod et al. 2002). Organic C was calculated by subtracting inorganic $\mathrm{C}$ from total C.

\section{Data Analysis}

All data analyses were conducted using JMP version 5 (SAS Institute 2002). Percent covers of shrubs, bare ground, downy brome, and perennial grasses were compared between herbicide treatments with ANOVA models containing the terms block (random effect), herbicide (fixed effect), herbicide $\times$ block (random effect), and subplot (fixed effect). Differences in methods precluded statistical comparisons between data from 2004 and data from 1995 or 1997. Therefore, we limit discussion of changes over time to qualitative differences in observed patterns of downy brome invasion. Mineral N and soil water were compared among microsites with ANOVAs containing the terms block (random effect), microsite (fixed effect), microsite $\times$ block (random effect), and date (fixed effect). Total organic C and $\mathrm{N}$, measured on only 1 date, were compared among microsites with ANOVAs containing the terms block (random effect) and microsite (fixed effect). Effects of herbicide were tested against the herbicide $\times$ block interaction in all analyses. For all variables compared among microsites, preplanned contrasts were used to determine whether dead sagebrush differed from live sagebrush. Response variables were natural log-transformed as 
necessary to correct for heteroscedasticity. For clarity, figures are presented on nontransformed axes.

\section{RESUlTS}

\section{Vegetation}

Eleven years following application, tebuthiuron treatment $\left(0.4 \mathrm{~kg}\right.$ ai $\left.\cdot \mathrm{ha}^{-1}\right)$ had reduced shrub cover by $52 \%$ (Fig. 1). Downy brome was common but patchily distributed, occurring in $48 \%$ of subplots. Tebuthiuron application increased downy brome cover approximately 4 -fold, from $0.9 \%$ in untreated plots to $3.5 \%$ in treated plots (Fig. 1). Perennial grasses occurred in $99.8 \%$ of subplots and also appeared to increase (from 9\% to $12.3 \%$ ) with tebuthiuron application, although this trend was only marginally significant $(F=12.9, P=0.07$; Fig. 1). Even though downy brome showed a much larger proportional increase in cover than did perennial grasses, their absolute increases in cover were similar. Due to the late-summer sampling date, cover values probably underestimate the maximum seasonal cover for both downy brome and perennial grasses. Percent bare ground also showed a marginally significant increase (from $39.1 \%$ to $43.9 \%$ ) with tebuthiuron application $(F=11.6, P=0.08$; Fig. 1).

\section{C, N, and Water Content of Soils}

Repeated measures analysis revealed that $\mathrm{NO}_{3}-\mathrm{N}$ concentration was significantly affected by both microsite (Fig. 2$)$ and date $(F=7.27$, $P<0.0001)$, but not by their interaction. Soil organic $\mathrm{C}$ and $\mathrm{N}$ were also significantly different among microsites (Fig. 2). Preplanned contrasts demonstrated that $\mathrm{NO}_{3}-\mathrm{N}$ concentration was higher under dead sagebrush than live sagebrush, but organic $\mathrm{C}$ and $\mathrm{N}$ did not differ between dead and live sagebrush (Fig. 2). $\mathrm{NH}_{4}-\mathrm{N}$ concentrations and soil water content were not influenced by microsite or date (data not shown).

\section{Discussion}

A decade after treatment with tebuthiuron, the herbaceous plant community has expanded, leading to little net change in bare ground, but the proportional increase of downy brome has been much larger than that of perennial grasses

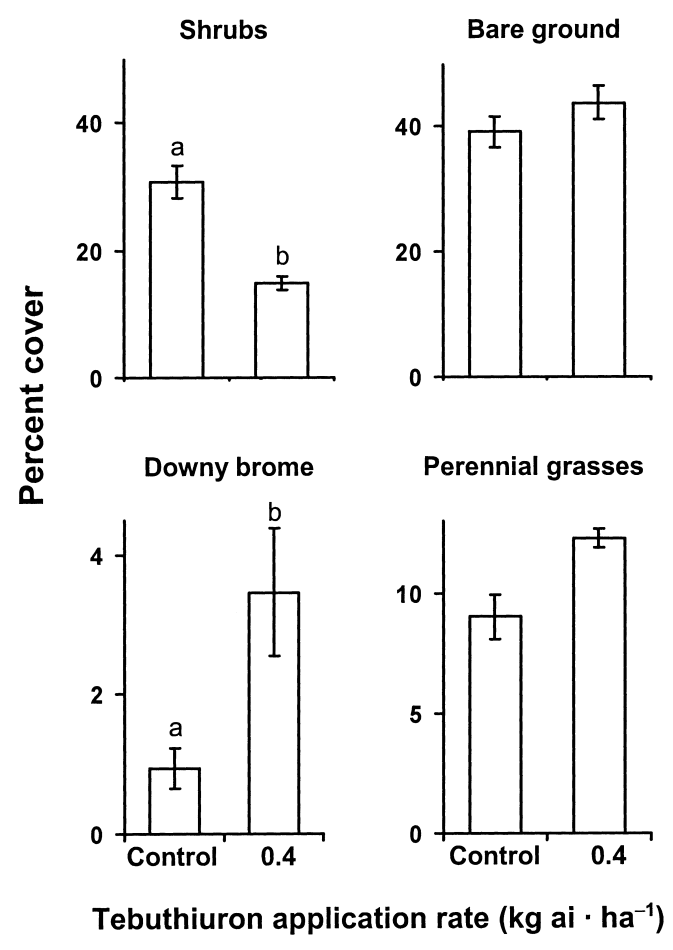

Fig. 1. Percent cover $\left( \pm 1 s_{\bar{x}}\right)$ of vegetation and bare ground in control and herbicide-treated plots 11 years after treatment with tebuthiuron. Note the differences in scale among y-axes. Bars with different letters are significantly different (shrubs: $F_{1,2}=609, P=0.002$; downy brome: $F_{1,2}=52.9, P=0.02$ ) based on split-plot ANOVAs conducted on natural log-transformed data. Herbicide was tested against the herbicide $\times$ block interaction.

(Fig. 1). This occurred even though downy brome was more patchily distributed (present in $48 \%$ of plots) than perennial grasses (present in $99 \%$ of plots) and therefore less likely to be exposed to increases in resources made available by shrub death. Although downy brome was locally abundant, its average cover was quite low, demonstrating that tebuthiuron has not yet led to a serious weed problem at this site. Nevertheless, the large proportional increase in downy brome cover suggests that tebuthiuron may have the potential to cause more serious infestations in future years or at other locations. Furthermore, our late-season measurements probably underestimate the contribution of both downy brome and perennial grasses to cover during peak season.

Multiple processes may have contributed to the relatively small proportional responses of perennial grasses relative to downy brome 

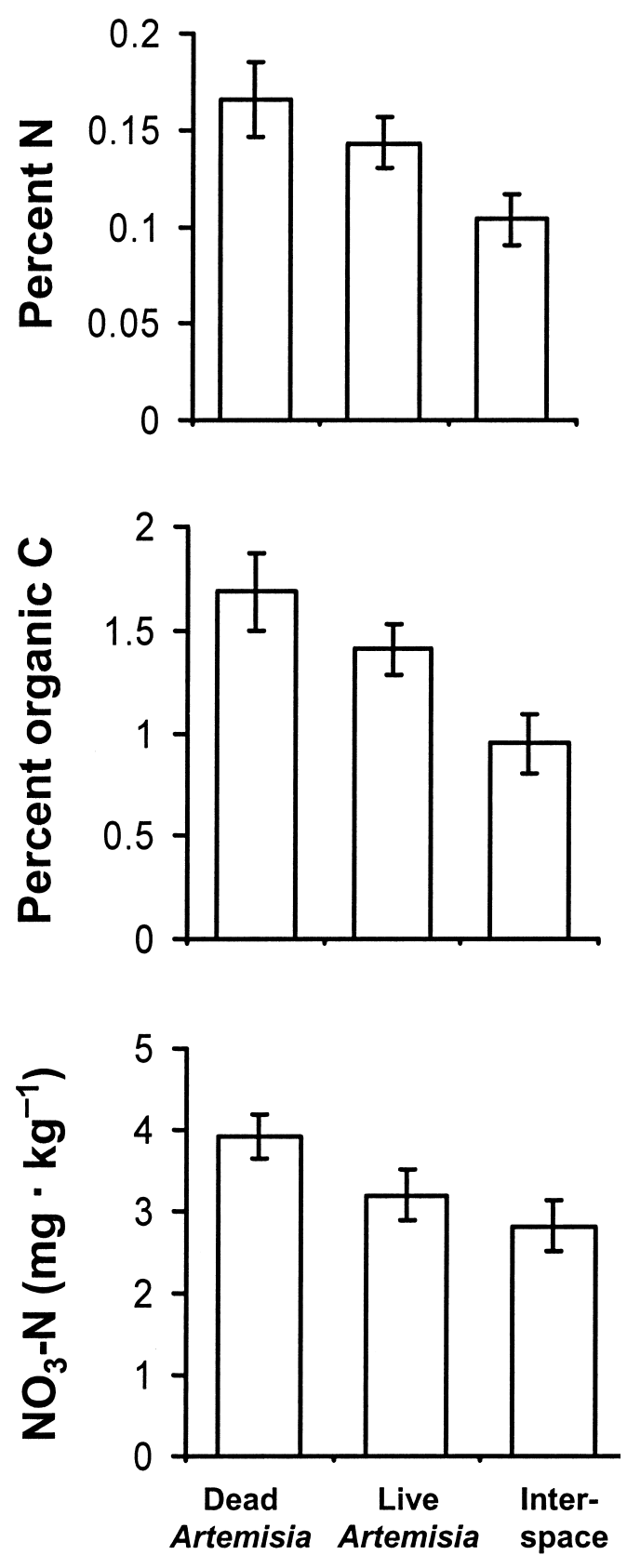

Fig. 2. The effect of microsite type on total organic $\mathrm{C}$ $(0-15 \mathrm{~cm})$, total $\mathrm{N}(0-15 \mathrm{~cm})$, and $\mathrm{NO}_{3}(0-15 \mathrm{~cm})$ concentration $\left( \pm 1 s_{\bar{x}}.\right)$. Effects of microsite were significant for $\mathrm{C}$ $\left(F_{2}{ }_{16}=11.3, P<0.001\right), \mathrm{N}\left(F_{2,16}=8.92, P=0.003\right)$, and $\mathrm{NO}_{3}\left(F_{2,10}=7.87, P=0.009\right)$, based on a split-plot ANOVA in which microsite was tested against the block $\times$ microsite interaction. Preplanned contrasts demonstrated that $\mathrm{NO}_{3}$ concentrations were significantly higher under dead sagebrush than live sagebrush $\left(F_{1,10}=6.67, P=\right.$ 0.03), but percent $\mathrm{C}\left(F_{1,16}=3.09, P=0.1\right)$ and percent $\mathrm{N}$ $\left(F_{1,16}=2.21, P=0.2\right)$ did not differ among the 2 microsites. at this site. Because of its rapid growth and high allocation of resources to dispersal, downy brome may have greater ability than perennial grasses to take advantage of newly available resources. In addition, annual grazing of the site may have limited perennial grass response to increased resource availability. It is also possible that the drought immediately preceding this sampling interacted with tebuthiuron, potentially increasing or decreasing the success of downy brome relative to that of perennial grasses.

While this is the longest running study to show a significant difference in downy brome cover between sagebrush thinning treatments, it is in accord with other studies in which downy brome was present prior to herbicide application (Piemeisel 1951, Hedrick et al. 1966, Olson and Whitson 2002). In addition to the 11 years since treatment, 2 lines of evidence suggest that the observed pattern of downy brome abundance may represent a relatively long-term change in the plant community. Four years after treatment this site showed a (nonsignificant) trend in the opposite direction, with more downy brome in control plots than in herbicide-treated plots (Olson and Whitson 2002). This suggests that the differences we measured developed between 4 and 11 years after treatment. Soil resource availability also differed more than 10 years after treatment, with higher $\mathrm{NO}_{3}-\mathrm{N}$ beneath dead sagebrush than beneath live sagebrush (Fig. 2). This may be the direct result of sagebrush death due to decreased uptake or increased decomposition and mineralization of dead sagebrush. Alternatively, higher $\mathrm{NO}_{3}-\mathrm{N}$ could result from downy brome invasion, as downy brome can influence $\mathrm{N}$ availability (Evans et al. 2001, Svejcar and Sheley 2001, Booth et al. 2003). Because high levels of available $\mathrm{NO}_{3}$ are also known to facilitate downy brome invasion and persistence (Paschke et al. 2000, Lowe et al. 2003), conditions may be favorable for continued expansion of downy brome at this site.

\section{CONCLUSIONS}

At this study site, downy brome invaded following sagebrush thinning despite patchy distribution of downy brome relative to that of perennial grasses. The slow expansion of perennial grasses relative to downy brome (Fig. 1) 
and the pattern of higher $\mathrm{NO}_{3}-\mathrm{N}$ availability under dead than live sagebrush plants (Fig. 2) suggest that dispersal and establishment of perennial grasses can be insufficient to monopolize newly available resources. The primary implication of these results for management is that even small populations of downy brome may have sufficient opportunity to find and exploit resources made available by shrub thinning.

\section{ACKNOWLEDGMENTS}

The authors are grateful for the contributions of Stan Clapp, Alicia Davisson, Cara Ferrier, Douglas Grant, Larry Griffith, Erik Hardy, Lachlan Ingram, Travis Laas, Matt Mortenson, Valerie O’Neill, Dettie Jo Osmon, Jerry Schuman, David Smith, and Ernie Taylor. Terry Booth, Dan LeCain, Thomas Monaco, Jack Morgan, and Matt Rinella provided useful comments on previous versions of this manuscript. Many thanks to Timothy McKinney for granting permission to work on his ranch.

\section{Literature Cited}

BAKER, H.G. 1965. Characteristics and modes of origin of weeds. Pages 147-172 in H.G. Baker and G.L. Stebbins, editors, The genetics of colonizing species. Academic Press, New York.

Bartolome, J.W., and H.F. Heady. 1978. Ages of big sagebrush following brush control. Journal of Range Management 36:65-67.

Booth, M.S., J.M. Stark, and M.M. Caldwell. 2003. Inorganic $\mathrm{N}$ turnover and availability in annual- and perennial-dominated soils in a northern Utah shrubsteppe ecosystem. Biogeochemistry 66:311-330.

Burke, I.C., W.A. Reiners, D.L. Sturges, and P.A. MatSON. 1987. Herbicide treatment effects on properties of mountain big sagebrush soils after fourteen years. Soil Science Society of America Journal 51:13371343.

Chapin, F.S. 1980. The mineral nutrition of wild plants. Annual Review of Ecology and Systematics 11: 233-60.

DaubenmiRe, R.F. 1959. A canopy-coverage method of vegetational analysis. Northwest Science 33:43-64.

DiTomaso, J.M. 2000. Invasive weeds in rangelands: species, impacts and management. Weed Science 48:255-265.

Evans, R.D., R. Rimer, L. Sperry, and J. Belnap. 2001. Exotic plant invasion alters nitrogen dynamics in an arid grassland. Ecological Applications 11:1301-1310.

Harniss, R.O., and R.B. Murray. 1973. 30 years of vegetal change following burning of sagebrush-grass range. Journal of Range Management 26:322-325.

Hedrick, D.W., D.N. Hyder, F.A. Sneva, and C.E. PoulTON. 1966. Ecological response of sagebrush-grass range in central Oregon to mechanical and chemical removal of Artemisia. Ecology 47:432-439.
Hulbert, L.C. 1955. Ecological studies of Bromus tectorum and other annual bromegrasses. Ecological Monographs 25:181-213.

Hull, A.C., JR., N.A. Kissinger, JR., and W.T. VAughn. 1952. Chemical control of big sagebrush in Wyoming. Journal of Range Management 5:398-402.

Hyder, D.N., AND F.A. Sneva. 1956. Herbage response to sagebrush spraying. Journal of Range Management 9:34-38.

Johnson, K.H., R.A. Olson, and T.D. Whitson. 1996. Composition of plant and small mammal communities in tebuthiuron-treated big sagebrush (Artemisia tridentata). Weed Technology 10:404-416.

Lowe, P.N., W.K. Lauenroth, and I.C. Burke. 2003. Effects of nitrogen availability on competition between Bromus tectorum and Bouteloua gracilis. Plant Ecology 167:247-254.

Mack, R.N., AND D.A. Pyke. 1983. The demography of Bromus tectorum: variation in time and space. Journal of Ecology 71:69-93.

McDaniel, K.C., L.A. ToRell, and C.G. OChOA. 2005. Wyoming big sagebrush recovery and understory response with tebuthiuron control. Rangeland Ecology and Management 58:65-76.

Miller, F.M., R.R. Findley, and J. Alderfer-Findley. 1980. Changes in mountain big sagebrush habitat types following spray release. Journal of Range Management 33:278-281.

Olson, R.A., AND T.D. Whitson. 2002. Restoring structure in late-successional sagebrush communities by thinning with tebuthiuron. Restoration Ecology 10: 146-155.

Paschke, M.W., T. McLendon, And E.F. Redente. 2000. Nitrogen availability and old-field succession in a shortgrass steppe. Ecosystems 3:144-158.

Piemeisel, R.L. 1951. Causes affecting change and rate of change in a vegetation of annuals in Idaho. Ecology 32:53-72.

SAS InSTITUTE. 2002. Statistics and graphics guide, version 5. SAS Instituite, Cary, NC.

Sherrod, L.A., G. Dunn, G.A. Peterson, and R.L. KolBERG. 2002. Inorganic carbon analysis by modified pressure-calcimeter method. Soil Science Society of America Journal 66:299-305.

Sturges, D.L. 1993. Soil-water and vegetation dynamics through 20 years after big sagebrush control. Journal of Range Management 46:161-169.

Svejcar, T., AND R. Sheley. 2001. Nitrogen dynamics in perennial- and annual-dominated arid rangeland. Journal of Arid Environments 47:33-46.

Western Regional Climate Center. Lander, Wyoming, monthly precipitation database. Accessed 3 February 2005. Available from: http://www.wrcc.dri.edu/index .html

Whitson, T.D., AND H.P. ALLEy. 1984. Tebuthiuron effects on Artemisia spp. and associated grasses. Weed Science 32:180-184.

Whitson, T.D., M.A. Ferrell, and H.P. Alley. 1988. Changes in rangeland canopy cover seven years after tebuthiuron application. Weed Technology 2:486-489.

Young, J.A., AND F.L. ALLEN. 1997. Cheatgrass and range science: 1930-1950. Journal of Range Management 50:530-535.

Received 7 July 2005

Accepted 17 February 2006 